UDC 616.12- 073.7

DOI: 10.20535/1810-0546.2017.1.91386

\author{
K.O. Ivanko*, N.G. Ivanushkina, Y.S. Karplyuk \\ Igor Sikorsky Kyiv Polytechnic Institute
}

\title{
IDENTIFICATION AND ASSESSMENT OF ELECTROCARDIOGRAPHIC MARKERS OF CARDIAC ELECTRICAL INSTABILITY**
}

Background. Development of the methods for identification and assessment of early signs of heart disorders makes it possible to catch the sight of disease at its initial stage. The article considers the methods of early diagnosis of the cardiovascular system using electrocardiographic markers of cardiac electrical instability.

Objective. The aim of the study is to identify low-amplitude components, which are inaccessible to standard procedures of electrocardiogram (ECG) evaluation by means of modern methods of registration, digital processing of electrocardiosignals and high resolution electrocardiography.

Methods. For detection of diagnostic symptoms associated with cardiac electrical instability, changes in real and simulated electrocardiosignals have been studied using different types of analysis: in time and frequency domains, scattergrams, cluster analysis, wavelet analysis and principal component analysis.

Results. The developed combined methods for analysis of low-amplitude components of electrocardiosignals allowed us to perform detection of late potentials, as well as T wave alternans, reflecting cardiac electrical instability.

Conclusions. Identification and evaluation of subtle manifestations of cardiac electrical activity are carried out. The use of the proposed method made it possible to distinguish the bursts of late potentials from the noise and to determine the temporal area of their localization.

Keywords: high-resolution electrocardiography; late potentials; T wave alternans; markers of cardiac electrical instability; clustering analysis; principal component analysis; eigenvectors basis; wavelet analysis.

\section{Introduction}

Development of diagnostic ECG systems of new generation is characterized by the use of complex mathematical transformations for estimation of parameters of electrical potentials considering biophysics and electrophysiology of myocardium. Among the systems that allow investigation of subtle manifestations of cardiac electrical activity, the systems of high resolution electrocardiography (HR ECG) should be noted [1-3]. Early diagnosis of the state of the cardiovascular system developed on the basis of HR ECG methods has essentially new opportunities and begins to be widely applied in clinical practice.

An important task aimed at improvement of risk stratification of patients is the search for additional predictors that can detect the fact of presence of vulnerable myocardium and predict the possibility of malignant arrhythmias. Apart from myocardial imaging techniques (magnetic resonance imaging, computed tomography, tissue Doppler), such electrocardiographic parameters as alternation of $\mathrm{T}$ wave and HR ECG with detection of atrial and ventricular late potentials can serve as the prognostic markers for the selection of patients for implantation of cardiovertersdefibrillators [1, 3].
The first signs of electrical instability of myocardium reflect changes in the electrophysiological processes occurring at the cellular level, which does not appear in the initial stage of the disease in the form of substantial functional and anatomical changes [1]. Development of the non-invasive methods for detection of the early signs of heart disease will enable diagnosis of the disease at early stage of its development. Digital processing of electrocardiographic signals makes it possible to extract information, which cannot be obtained by the visual analysis of the standard electrocardiogram $[3,4]$.

\section{Problem statement}

The aim of the study is improvement of methods and tools for automated detection of low amplitude components of electrocardiosignals through development of methodological and algorithmic support of high resolution ECG systems.

Biophysical bases of genesis of myocardial electrical instability markers

Atrial and ventricular late potentials. Non-invasive technology of high-resolution electrocardio-

\footnotetext{
* corresponding author: koondoo@gmail.com

${ }^{* *}$ The authors gratefully acknowledge the support of the project AMMODIT funded within EU H2020-MSCA-RICE
} 
graphy performed by improving of technical facilities and digital processing of electrocardiosignals allows registration and identification of low amplitude signals, which are not visible on a conventional electrocardiogram. The most extensively studied markers of myocardial electric instability are atrial and ventricular late potentials (ALP and VLP). Ventricular late potentials are the low-amplitude $(20-40 \mu \mathrm{V}$ from the body surface) high-frequency $(40-250 \mathrm{~Hz}$ ) electrical signals, which are localized at the end of QRS complex or beginning of ST segment and have a duration of a few tens of milliseconds (Fig. 1). Atrial late potentials are the ow-amplitude high-frequency signals $(5-20 \mu \mathrm{V})$, which are located at the end of $\mathrm{P}$ wave or within the isoelectric part of cardiac interval PQ. It is thought that ALP are the markers of atrial tachyarrhythmias and VLP are the markers of ventricular tachyarrhythmias that develop through the "re- entry" mechanism. The emergence of late potentials in ECG signal reflects the slow and fragmented depolarization associated with the "re-entry" circles [1]. The causes of propagation disturbances of excitation pulse can be anatomical or functional.

Noninvasive registration from the body surface, identification and analysis of late potentials are the challenging tasks due to the fact that amplitude of late potentials may be much smaller than the amplitude of the noise components of ECG [1-4]. Noise and interferences occurring in the ECG signal have the different nature and include: power line interference; polarization of the electrodes, resulting in a shift of the zero signal level; artifacts of electrodes displacement; motion artifacts; muscular activity; baseline drift caused by breathing; noise of electronic equipment. To eliminate noise and reveal lowamplitude ECG components, computer signal ave-
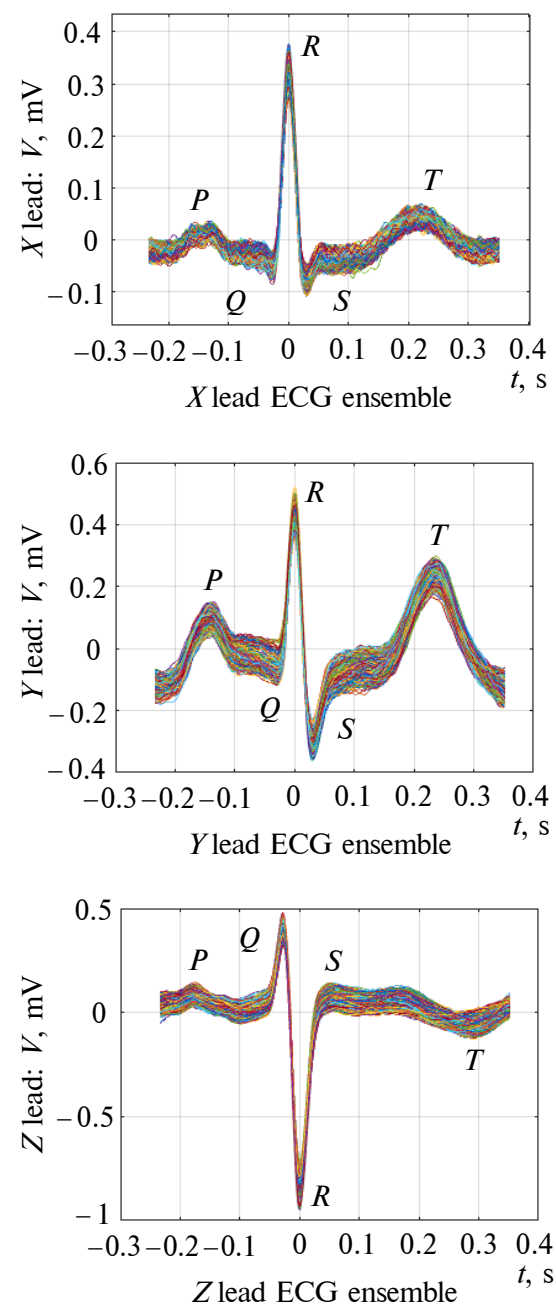

$a$
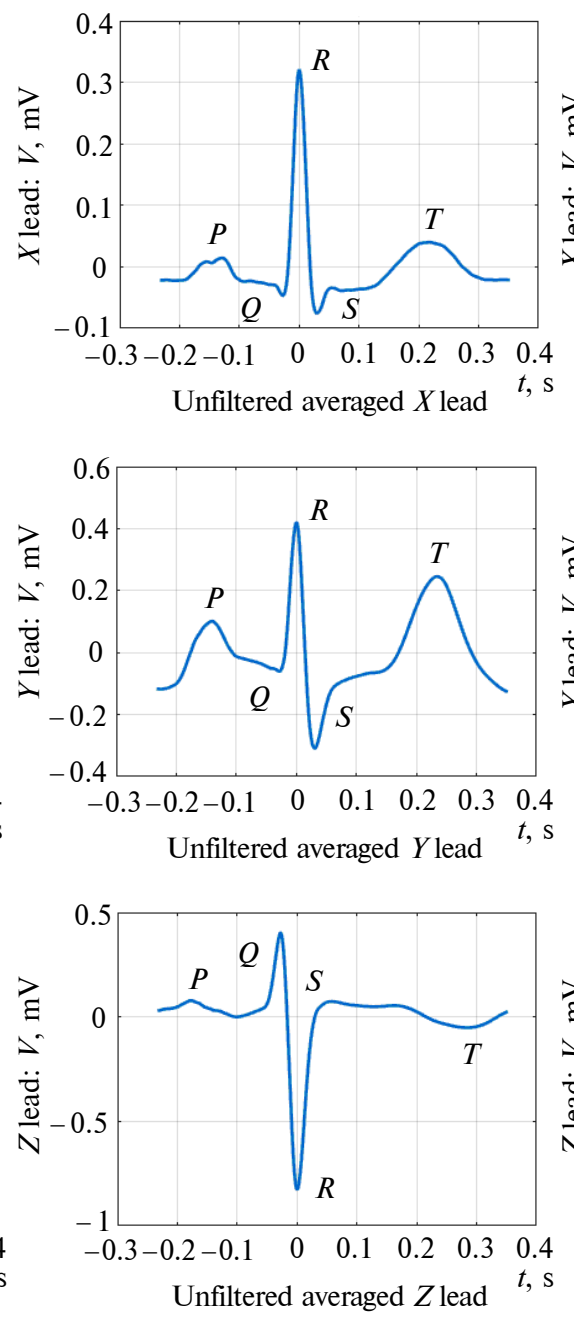

$b$
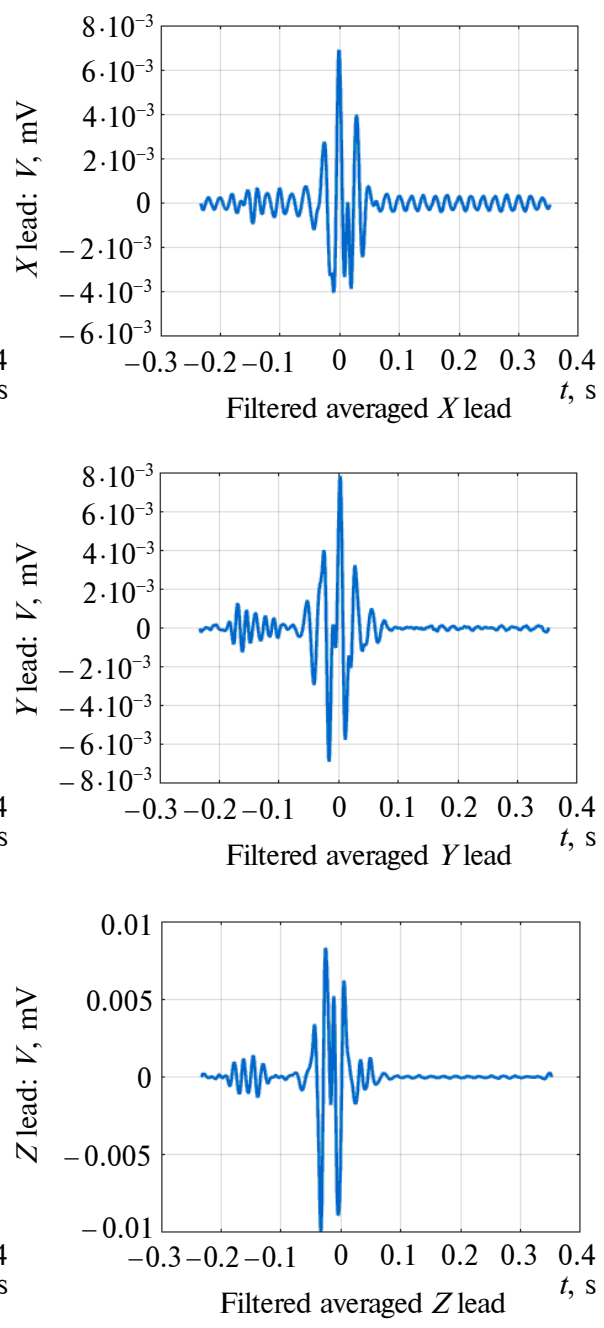

$c$

Fig. 1. Accumulation of cardiocycles with synchronization on $\mathrm{R}$ wave in three orthogonal Frank leads $X, Y, Z(a)$; averaging of cardiosignal (b); filtration in the frequency range of $40-250 \mathrm{~Hz}(c)$ 
raging is performed. It is based on the property of the repeatability of ECG signal and implements the principle of pseudo synchronous accumulation. Averaging of multiple cardiocycles (from 100 to 400 ECG complexes) forms the basis of high-resolution electrocardiogram. The method allows us to separate signal from noise by a significant improvement in signal/noise ratio. Since noise is a random process, it is not synchronized with the investigated electrocardiosignal. Noise superimposes randomly from one complex to another, which leads to a significant reduction in its amplitude when averaging. In contrast to the noise, diagnostically useful cardiosignal repeats with a certain frequency (not chaotically), therefore its amplitude stabilizes due to the averaging. As a result of averaging, the signal/noise ratio increases.

Implementation of temporal analysis according to the Simson method involves averaging of cardiosignal in three orthogonal Frank leads $X, Y$, $Z$, followed by filtration in the frequency range of $40-250 \mathrm{~Hz}$ (Fig. 1). Analysis of their total vector magnitude $\sqrt{X^{2}+Y^{2}+Z^{2}}$ determines the time and amplitude quantitative parameters, based on which conclusion about the presence or absence of late potentials is made (Fig. 2).

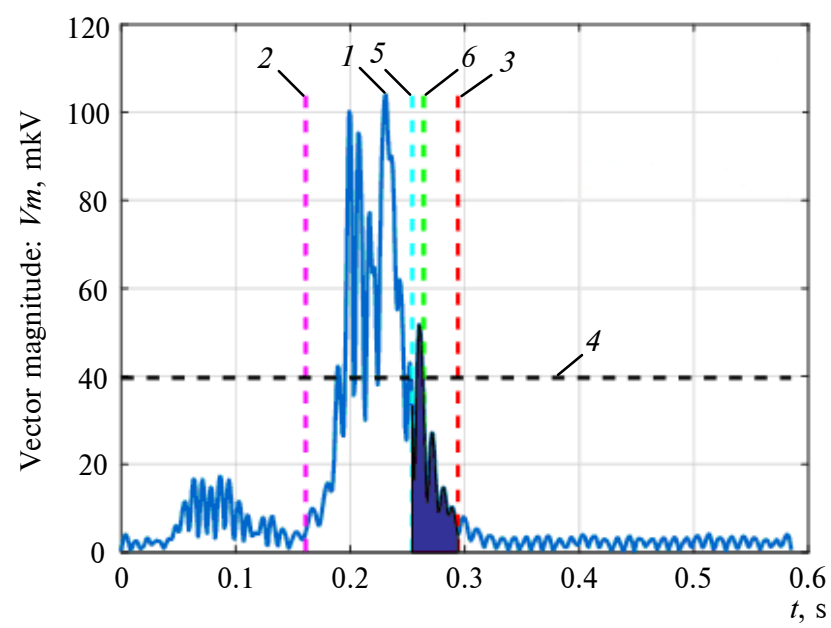

Fig. 2. Analysis of total vector magnitude $\sqrt{X^{2}+Y^{2}+Z^{2}}$ for detection of ventricular late potentials: $1-$ vector magnitude; 2 - QRS-on; 3 - QRS-off; 4 - $40 \mathrm{mkV}$; 5 QRS last $40 \mathrm{~ms} ; 6$ - below $40 \mathrm{mkV}$

T wave alternans. Another task of extraction of diagnostically important information from the surface electrocardiogram is analysis of the electrical alternans of ventricular repolarization. Identification and evaluation of $\mathrm{T}$ wave alternans is a promising direction in electrocardiography. The term " $\mathrm{T}$ wave alternans" (TWA) refers to the alternation of ampli- tude or temporal characteristics of the ST interval and $\mathrm{T}$ wave (ST-T complex) and involves measuring of the differences in the amplitude, shape, and/or time of the $T$ wave in successive cardiac cycle $[5,6]$.

The appearance of TWA on the ECG can be explained by the presence of repolarization alternation at the level of ventricular cardiomyocytes. TWA reflects periodic beat-to-beat variation in the electrophysiological characteristics of the myocardial cells in various pathological processes that leads to violations of repolarization of cardiomyocytes, and serves as a predictor of life-threatening ventricular tachyarrhythmias. Macro and micro alternans can be distinguished on ECG. Macro alternans is apparent on the ECG with the naked eye and represents significant change in the morphology of the $\mathrm{T}$ wave (its amplitude, shape, length, polarity). Microvolt level beatto-beat fluctuations could not be revealed by visual inspection and demand advanced digital processing techniques and computational algorithms for their detection and assessment.

It is thought that TWA is the result of spatial or temporal dispersion of repolarization $[5,6]$. Heterogeneity of electrophysiological properties of the myocardium cells (spatial changes in duration, shape or speed of propagation of action potentials) forms a substrate for reentry mechanism (mechanism of excitation wave reentry), which consequently leads to arrhythmia. TWA is closely associated with arrhythmogenic mechanisms and reflects the propensity of the myocardium to the development of ventricular tachyarrhythmias, therefore, it is believed to be a marker of increased risk of sudden cardiac death.

$A B A B$ pattern is typical for $T$ wave alternans, wherein one type of $T$ wave is observed in the odd cardiocycles (type A, the waves with a lower amplitude in Fig. 3), and the different type of T wave can be seen in the even cardiocycles (type B, the waves with a larger amplitude in Fig. 3). However, the other types of alternans are believed to be possible, when at some point of time a change of phase of alternans occurs, such as in ABBABA pattern.

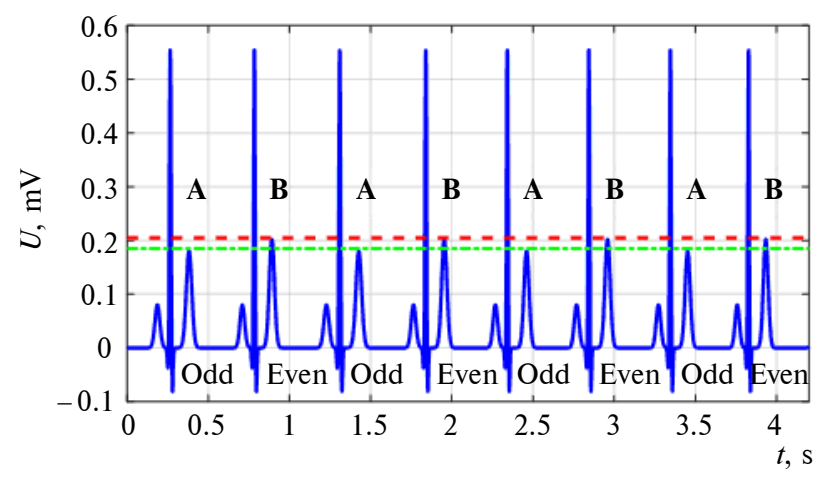

Fig. 3. Typical for $T$ wave alternans ABAB pattern 
$\mathrm{T}$ wave alternans is associated with the dispersion of repolarization and reflects variation that periodically appears in each succeeding cardiocycle. Significant spatial and temporal dispersion of repolarization, variation of the propagation velocity of excitation pulse, fluctuation of the ionic currents, and alternation of duration and shape of the action potentials in cardiac cells lead to arrhythmias. Repolarization alternans at the cellular level, observed in direct recordings of action potentials from the surface of the heart, are several orders of magnitude greater than the manifestation of TWA on the surface ECG. This fact explains why even micro-volt changes on the surface ECG, as TWA manifestation, reflect significant abnormalities of repolarization of cardiomyocytes membrane and have clinical importance.

The peculiarity of the $\mathrm{T}$ wave alternans analysis is the need of its assessment within a certain range of heart rate. $\mathrm{T}$ wave alternans occurs at a significant increase in heart rate above a certain threshold. Usually, TWA appears with an increase in heart rate up to $100-110$ beats/minute, so it is mainly evaluated during the exercise test, pharmacological stress tests, electrocardiostimulation, or according to the daily ECG monitoring. When heart rate is greater than 110 beats/minute, alternans of repolarization may occur in healthy people. A high heart rate can result in overload and disruption of the cell's ability to maintain calcium homeostasis during myocardial contraction. This leads to an alternation in the calcium circulation process and consequently to alternating action potential duration $[5,6]$.

The relevance of using $T$ wave alternans as a noninvasive diagnostic indicator is not in doubt. However, the detection and assessment of the level of $\mathrm{T}$ wave alternans from surface ECG data is quite challenging, as the visually implicit changes in $\mathrm{T}$ wave amplitude have a level of from units to several tens of microvolts, while the amplitude of the $\mathrm{T}$ wave is $0.3-0.7 \mathrm{mV}$. Furthermore, the real ECG signals are usually highly distorted by noise components of biological and nonbiological origin.

The Database used in the current study of TWA is provided by The PhysioNet resource (T Wave Alternans Challenge Database) and contains 100 multichannel ECG records sampled at $500 \mathrm{~Hz}$ with 16 bit resolution and approximate duration of two minutes [7, 8]. It includes recordings from patients with myocardial infarctions, transient ischemia, ventricular tachyarrhythmias, and other risk factors for sudden cardiac death, as well as healthy controls and synthetic cases with TWA.

The stage of ECG signal preprocessing is very important for TWA identification and assessment. Even a very weak residual noise can lead to a false- positive result. In the present study preprocessing stage included the elimination of baseline drift and high-frequency noise suppression. The wavelet based multiresolution analysis was applied to remove baseline fluctuations. Wavelet decomposition was performed up to the 12th level of the raw ECG data using Symmetric wavelet of 6th order. The 12th order approximation function and the detail functions from 9 to 12 orders, which reflect slow changes of signal, were not taken into account during signal recovery. To remove high-frequency noises, the spectrum of the previously detrended data was limited up to $30 \mathrm{~Hz}$ using FIR Window Lowpass filter.
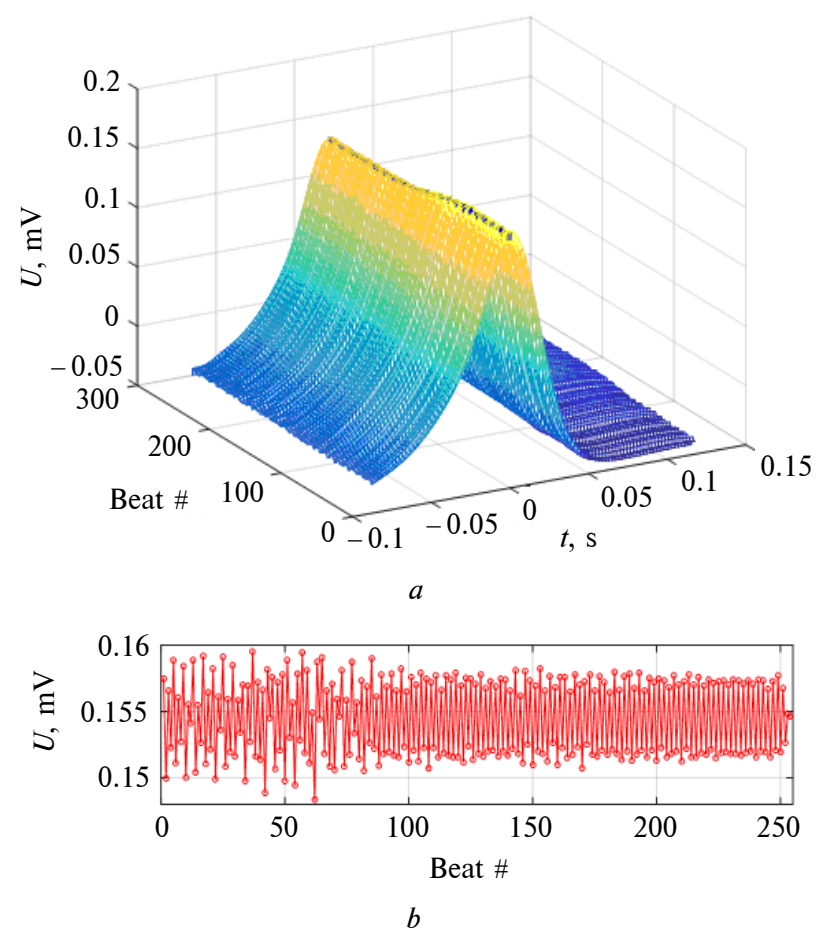

Fig. 4. Synchronization of the ensemble of $\mathrm{T}$ waves according to their maximums $(a)$; dependence of the amplitude of the $T$ wave from the number of the cardiac cycles in case of presence of repolarization alternans $(b)$

The next stage of the algorithm is detection of $\mathrm{R}$ waves maximums on ECG. For this purpose the ECG signal was twice differentiated and squared, which made it possible to find extremes of QRS complexes and determine the position of $\mathrm{R}$ waves on ECG [9]. Then peaks of $T$ waves were identified on ECG. Investigation of $\mathrm{T}$ wave alternans with a change in its amplitude and/or morphology involves the alignment of ensemble of $\mathrm{T}$ waves on their maximums (Fig. 4, a). In case of absence of repolarization alternans, amplitudes of the $\mathrm{T}$ waves in ECG signal represent a realization of one random variable, which varies with certain dispersion with respect to the average value of the amplitude of $T$ wave. In case 
of presence of repolarization alternans, amplitudes of the T waves in ECG signal are the realizations of two random variables that vary with given variances with respect to their mathematical expectations on the condition of alternation of these characteristics in consecutive cardiac cycles. Here the dependence of the amplitude of the $T$ wave from the number of the cardiac cycle has a sawtooth character (Fig. 4, b).
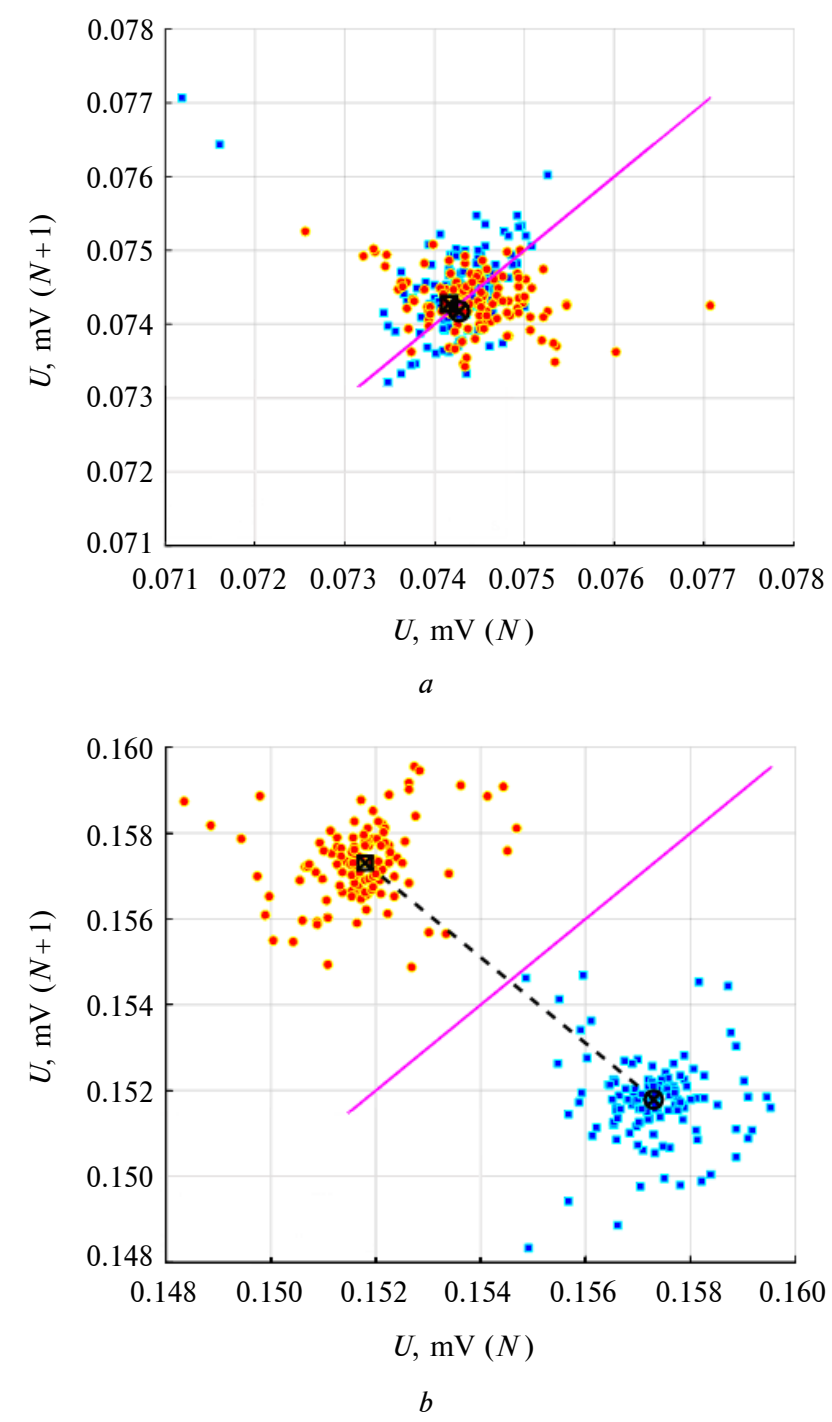

Fig. 5. The cluster analysis of scattergram: $a-$ absence of repolarization alternans; $b$ - presence of repolarization alternans: $\mathbf{m}$ - odd; $\bullet$ - even; - - bisector; $\boldsymbol{\square}$ - center of the first cluster; $\mathbf{O}$ - center of the second cluster; - - distance between the centers of the clusters

The scatter-plot method of TWA analysis involves graphical representation of the $\mathrm{T}$ wave amplitude (or another feature, for instance, the area under the curve of $T$ wave) of each beat against its successor in coordinate plane. Area of the points obtained in this way is called scattergram (scatter-plot, Poin- care or Lorenz plot). Cluster analysis of scattergram can be used as for ABABAB pattern of alternans as for $\mathrm{ABCABC}$ pattern. Scattergram represents a set of points, the center of which is located on the bisector. The deviation of the point from the bisector to the left indicates how much more is the $\mathrm{T}$ wave amplitude of $N+1$ beat comparing to the T wave amplitude for the previous beat $(N)$; deviation of the point from the bisector to the right demonstrates how much less is the T wave amplitude of $N+1$ beat comparing to the $\mathrm{T}$ wave amplitude of the previous beat $(N)$.

Comparing scattergrams obtained for the cases of TWA presence and TWA absence, we can observe one cluster of points in the case of TWA absence (Fig. 5, a) and the apparent separation of the set of points into two clusters corresponding to the amplitudes of $T$ waves from even and odd ECG cardiocycles in the case of TWA presence of ABAB pattern (Fig. 5, b). Three clusters are observed in scattergram in case of alternans of ABCABC type.

The amplitude of $T$ wave alternans is estimated by measuring the distance between the centers of the two clusters, which were obtained in scattergram for even and odd cardiocycles. The cluster analysis of scattergram involves assessment of intercluster distance $S_{e}$, which is calculated between the centers of two clusters (Fig. 5, $b$ ), and the average sum of squares of intracluster distances $S_{i}$, which were found for each of the clusters. The squared Euclidean distance measure was used.

\section{The combined approach for processing of low- amplitude components of electrocardiosignals}

Existing methods of analysis of low-amplitude components of electrocardiosignals can be divided into two classes, depending on the availability of a priori information about the investigated signals. The knowledge of time and/or frequency characteristics of the signals and the use of standard basic functions is typical for the I-st class of methods. For the II-nd class of methods, on the basis of a minimum of a priori information about signal properties, the eigen basic functions derived from the data are applied. For the analysis of low-amplitude components of electrocardiosignals a combined approach, which includes several stages with the use of methods of analysis of the I-st and the II-nd classes, is encouraged to use: wavelet transformation, decomposition in the basis of eigenvectors, principal component analysis [10-13]. For tasks of processing of low-amplitude components of ECG the different combinations of these methods can be utilized [3, 4, 9-13]. 
Each $i$-realization in the ensemble of registered electrocardiosignals corresponds to a set of samples $E_{i}=\left[e_{i 1}, e_{i 2}, \ldots e_{i N}\right]$, where $N$ is the amount of samples. The ensemble of $M$ realizations can be presented as matrix $E$. Then the matrix of the ensemble of observations $E$ and the covariance matrix $C$ obtained for the ensemble of observations can be written as follows:

$$
E=\left[\begin{array}{cccc}
e_{11} & e_{12} & \ldots & e_{1 N} \\
e_{21} & e_{22} & \ldots & e_{2 N} \\
\vdots & \vdots & & \vdots \\
e_{M 1} & e_{M 2} & \ldots & e_{M N}
\end{array}\right], \quad C=\left[\begin{array}{cccc}
c_{11} & c_{12} & \ldots & c_{1 N} \\
c_{21} & c_{22} & \ldots & c_{2 N} \\
\vdots & \vdots & & \vdots \\
c_{N 1} & c_{N 2} & \ldots & c_{N N}
\end{array}\right]
$$

where the elements $c_{i j}$ of the matrix $C$ can be presented as follows

$$
c_{i j}=\sum_{k=1}^{M}\left(e_{k i}-m_{k}\right)\left(e_{k j}-m_{k}\right),
$$

$m_{k}$ is the average value calculated for the $k$-th realization.

With the methods of decomposition in the basis of eigenvectors and principal component analysis, the subspaces of eigen basic functions, which are determined from observations of the ensemble of electrocardiosignals, are constructed.

The method of decomposition in the basis of eigenvectors and principal component analysis decorrelate the ensemble of registered electrocardiosignals by projecting the data on the orthogonal axes of the eigenvectors of the covariance matrix:

$$
E=U D V^{T},
$$

where $E$ is observations matrix (the ensemble of registered electrocardiosignals) with dimension $M \times N$; $D$ is the diagonal matrix with diagonal elements equal to the square root of the eigenvalues $\lambda_{i}$ of the covariance matrix $C ; V$ is $N \times N$ matrix of eigenvectors of the covariance matrix $C$; $U$ is $M \times M$ matrix of $E$ projections on the eigenvectors of matrix $C$.

Performing principal component analysis, the major eigenvectors corresponding to the most significant eigenvalues are retained $(p<<M)$. According to the set of the major eigenvectors, a new matrix of ECG observations is constructed with filtration from noise components:

$$
E_{\text {new }}=U D_{p} V^{T},
$$

where $D_{p}$ is the diagonal matrix with diagonal elements equal to the square root of the most significant eigenvalues $\lambda_{i}$ of the covariance matrix $C$.
On the basis of wavelet decomposition, electrocardiosignals preprocessing and postprocessing can be performed, resulting in the formation of the subspace of wavelet coefficients of low amplitude components $Y$.

By means of multiresolution wavelet transform, ECG signal can be represented as a sum of an approximation component $A_{m}$ and the detail components $D_{j}$ :

$$
E(t)=A_{m}(t)+\sum_{j=1}^{m} D_{j}(t),
$$

where $m$ is the number of wavelet decomposition levels.

The approximation coefficients of multiresolution wavelet transform correspond to the low-frequency components of ECG signal and the detail coefficients correspond to high frequency components.

Depending on the features of detectable pathology, signs of low amplitude components of electrocardiosignals can be found either at lower levels of detail components (for high-frequency character of identified components), or at the highest levels of detail components (for low-frequency character of identified components).

\section{Numerical experiments}

Identification of late potentials and $\mathrm{T}$ wave alternans in the recorded ECG signals is a difficult task because of noise components comparable in amplitude with the low amplitude components of electrocardiosignals, as well as imposition of time and frequency ranges of the signals of normal and abnormal heart electrical activity. A promising direction for solving this problem is the use of a combined approach.

Combined method for the analysis of the subtle structure of electrocardiosignal for identification of late potentials. Extraction and evaluation of late potentials is possible to perform through the creation of eigensubspaces of wavelet patterns of low-amplitude components of ECG. Suggested procedure for atrial late potentials recognition is based on the determination of eigenvalues and eigenvectors of the covariance matrix defined for wavelet coefficients sets, which comprise signs of late potentials and specified for each $\mathrm{P}$ wave in the ensemble of ECG realizations.

Eigenvector $\mathbf{V}_{1}$ of covariance matrix $\mathbf{C}_{\mathrm{w}}$, defined for wavelet coefficients sets with signs of late potentials, corresponds to the largest eigenvalue $\lambda_{1}$. The first principal component determined by eigenvector $\mathbf{V}_{1}$ can be considered as a filtered set of the 
detail wavelet coefficients $c D_{1}$. The signal reconstructed on this set of wavelet coefficients can be considered as a component of ECG that in the case of atrial delayed depolarization contains the signs of late potentials purified from noise and high-amplitude $\mathbf{P}$ wave part. The remaining vectors of eigenbasis characterize the noise subspace, concretely, a mixture of the less significant components of the useful signal with physiological interferences and uncorrelated measuring noise.

In order to detect signs of atrial late potentials on the background of noise by means of the proposed method, a model experiment was conducted. The real ECG recordings preliminary filtered from the high-frequency components were considered as the norm without ALP. Then, additive white gaussian noise was added to these signals. At the initial assumption about the possibility of the "norm" and "pathology", cardiocycles with such P waves are normal, because they do not contain ALP. Further in the terminal part of each distorted by noise $\mathrm{P}$ wave the simulated late potentials were added. Analysis of cardiocycles with such $\mathrm{P}$ waves involves the detection of late potentials on the background noise. For the initial ensembles of cardiosignals the sets of wavelet coefficients $c D_{1}$ were obtained by means of wavelet decomposition up to the 5th level with a "symmetric" wavelet of the 4th order.

Parameter

$$
L=\frac{\lambda_{i}}{\sum_{k=1}^{N} \lambda_{k}} \cdot 100 \%
$$

makes sense of the part of the variance in percentage, which is used to estimate the proportion of the information contained in the component determined by the eigenvector $\mathbf{V}_{i}$.

The obtained sets of eigenvalues explain the use of the component determined by the first eigenvector $\mathbf{V}_{1}$. For example, decomposition in a basis of eigenvectors performed for wavelet coefficients $c D_{1}$ of the ECG signals with ALP presence in background noise obviously shows that the largest proportion of the dispersion corresponds to the first principal component (Fig. 6, b). The proportion of the variance is approximately equal for remaining eigenvalues and determined by the noise components. In absence of ALP wavelet coefficients contain only noise and, consequently, the proportion of the variance for the first component is not significantly higher than the corresponding parameter for the other components in the set of 10 eigenvalues (Fig. 6, a). Reconstruction in the time-am- plitude domain was made by inverse wavelet transform performed using only the main first component of wavelet coefficients $c D_{1}$ (Fig. 7). The use of the proposed complex method made it possible to distinguish ALP bursts from the noise and determine the temporal area of their localization. For $\mathrm{P}$ waves corresponding to the absence of ALP reconstructed output signal does not contain highamplitude ALP bursts above the general noise level.
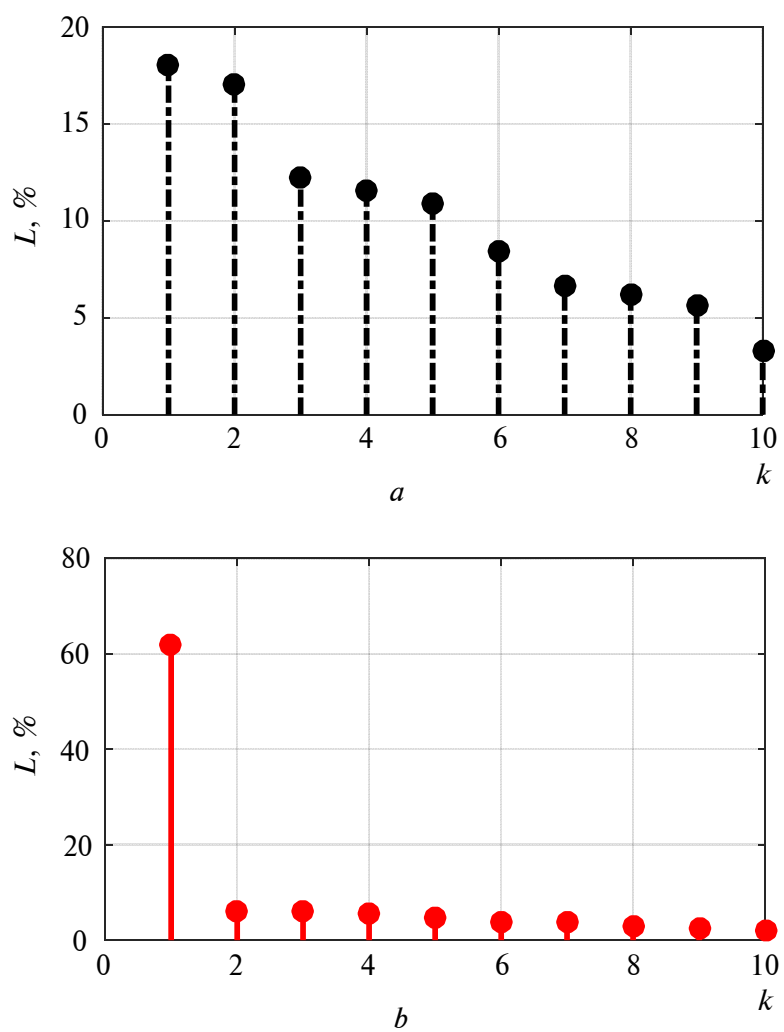

Fig. 6. Parameter $L$ for the first 10 eigenvalues: $a$ - absence of ALP; $b$ - presence of ALP

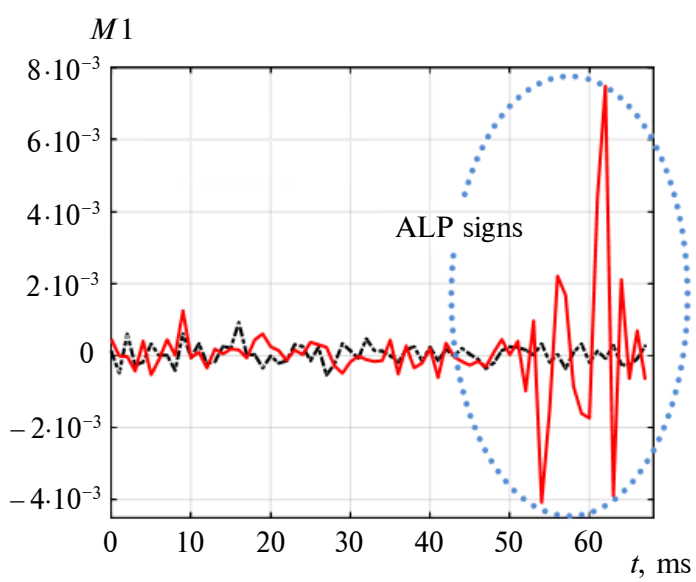

Fig. 7. The first main component corresponding to the largest eigenvalue for the cases of absence and presence of ALP in noise: --. - ALP absence; — - ALP presence 
Numerical characteristics of wavelet coefficients, allowed us to obtain non-overlapping clusters for 2 classes in ALP pattern recognition: "norm - ALP absence" and "pathology - ALP presence" (Fig. 8). Parameter $Z$ was determined as ratio of the first eigenvalue to the sum of all eigenvalues of the covariance matrix for an ensemble of detail wavelet coefficients $c D_{1} . M$ parameter was determined as maximum of the absolute values of the signal $A$, reconstructed by the main component of the detail coefficients $c D_{1}: M=\max |A|$.

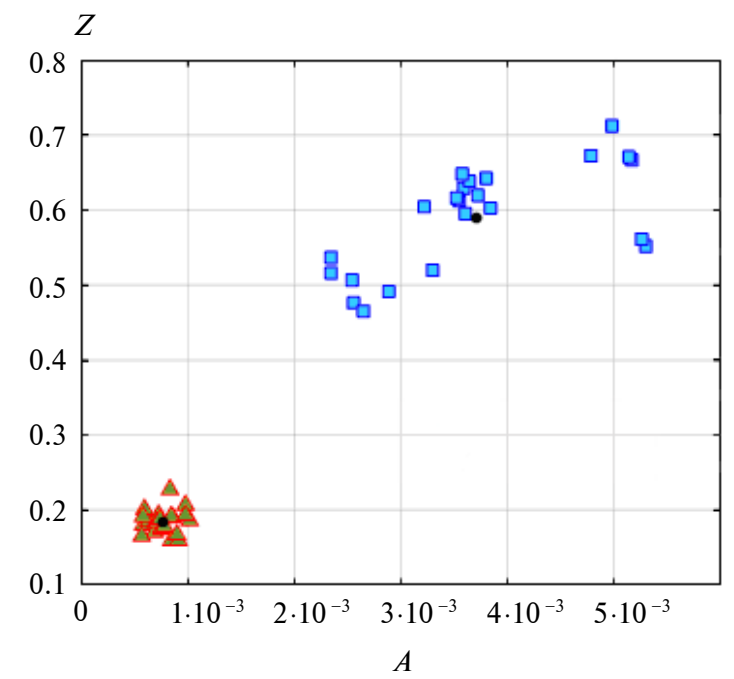

Fig. 8. The results of data clustering: $\square-$ ALP presence; $\Delta-$ ALP absence

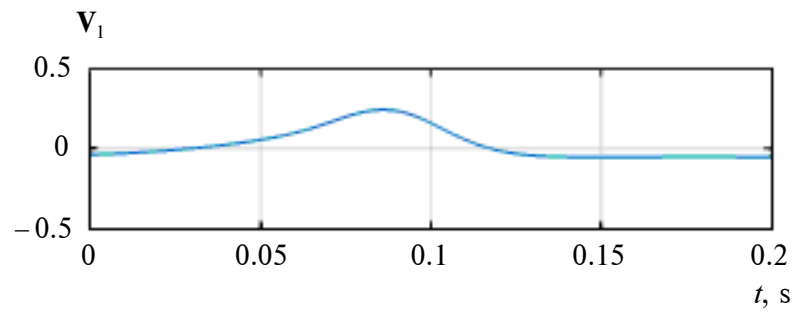

$\mathbf{V}_{2}$

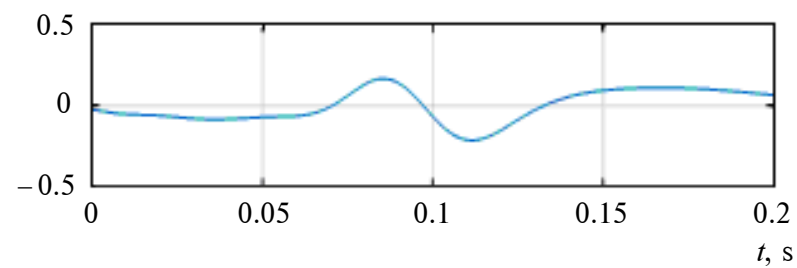

$\mathbf{V}_{3}$

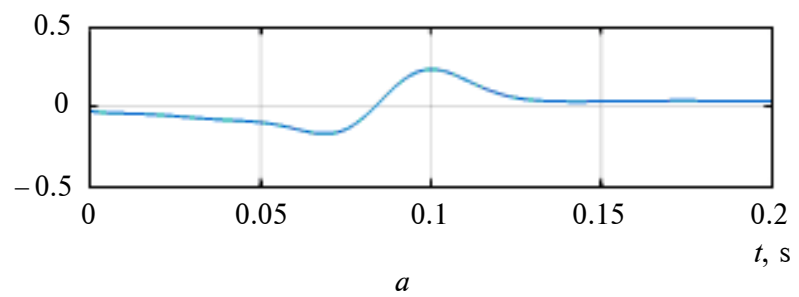

Identification and evaluation of $T$ wave alternans using principal component analysis. The method of principal components analysis implies decorrelation of the ensemble of $T$ waves through the data projection on the orthogonal axes of eigenvectors of the covariance matrix [10]. Error of T wave reconstruction in coordinate basis of principal eigenvectors depends on the number of eigenvectors, which are discarded during reconstruction. It is enough to take into account from 3 to 5 major eigenvectors and their eigenvalues for the analysis of $\mathrm{T}$ wave alternans.

The decomposition of the ensemble of $\mathrm{T}$ waves consists of calculating $b_{i j}$ coefficients, which are the projections of the signal on the eigenvectors (Fig. 9). Analysis of $b_{i j}$ coefficients allows assessment of beatto-beat changes in the amplitude and shape of $\mathrm{T}$ wave. Depending on the complexity of violations of repolarization in myocardial cells, beat-to-beat changes in the morphology of $\mathrm{T}$ wave may comprise as subtle variations of shape, as apparent modifications, including even change of $\mathrm{T}$ wave polarity. $\mathrm{ABAB}$ pattern of alternans corresponds to one form of $\mathrm{T}$ wave in even of cardiac cycles and to another form in odd cardiac cycles. In case of alternans that manifests itself as beat-to-beat changes in $\mathrm{T}$ wave morphology, the values of the coefficients $b_{i j}$ form distinct clusters corresponding to even and odd cardiac cycles.

For ECG signals with the absence of $T$ wave alternans the presence of one cluster of points formed by the values of the coefficients $b_{1}-b_{3}$ of eigen-

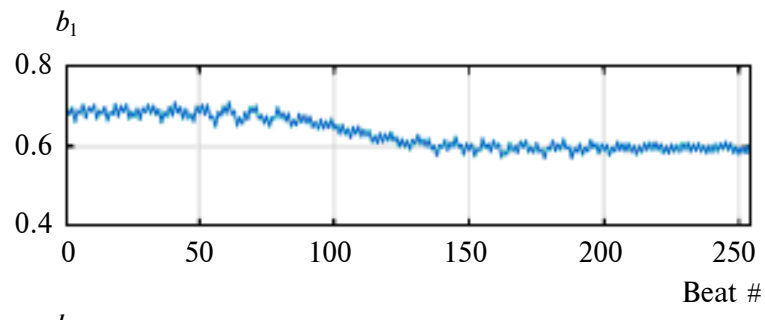

$b_{2}$

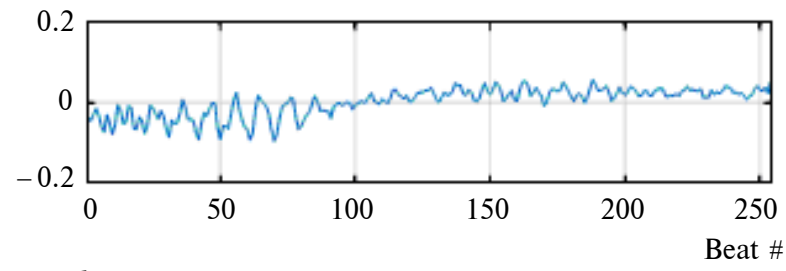

$b_{3}$

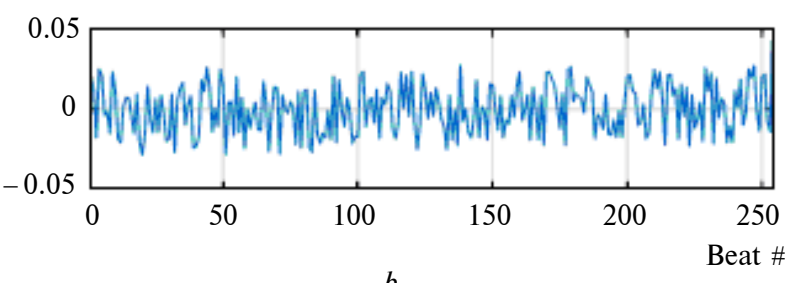

Fig. 9. The first 3 eigenvectors $\mathbf{V}_{1}-\mathbf{V}_{3}(a)$ and their coefficients $b_{1}-b_{3}(b)$ 
vectors $\mathbf{V}_{1}-\mathbf{V}_{3}$ is observed (Fig. 10, $a$ ). For ECG signals with $\mathrm{T}$ wave alternans the presence of two clusters in the space of features can be seen (Fig. 10, b). These clusters of points correspond to odd and even cardiac cycles. That means that there are two main (base) shapes, around which the shape of $\mathrm{T}$ waves fluctuates in odd and even cardiac cycles. These basic shapes of $\mathrm{T}$ wave for even and odd cardiocycles are calculated using the coefficient values of the respective centers of the clusters (Fig. 11) by obtaining a linear combination of the vectors $\mathbf{V}_{1}-\mathbf{V}_{3}$ multiplied by the coefficients $b_{1}-b_{3}$.
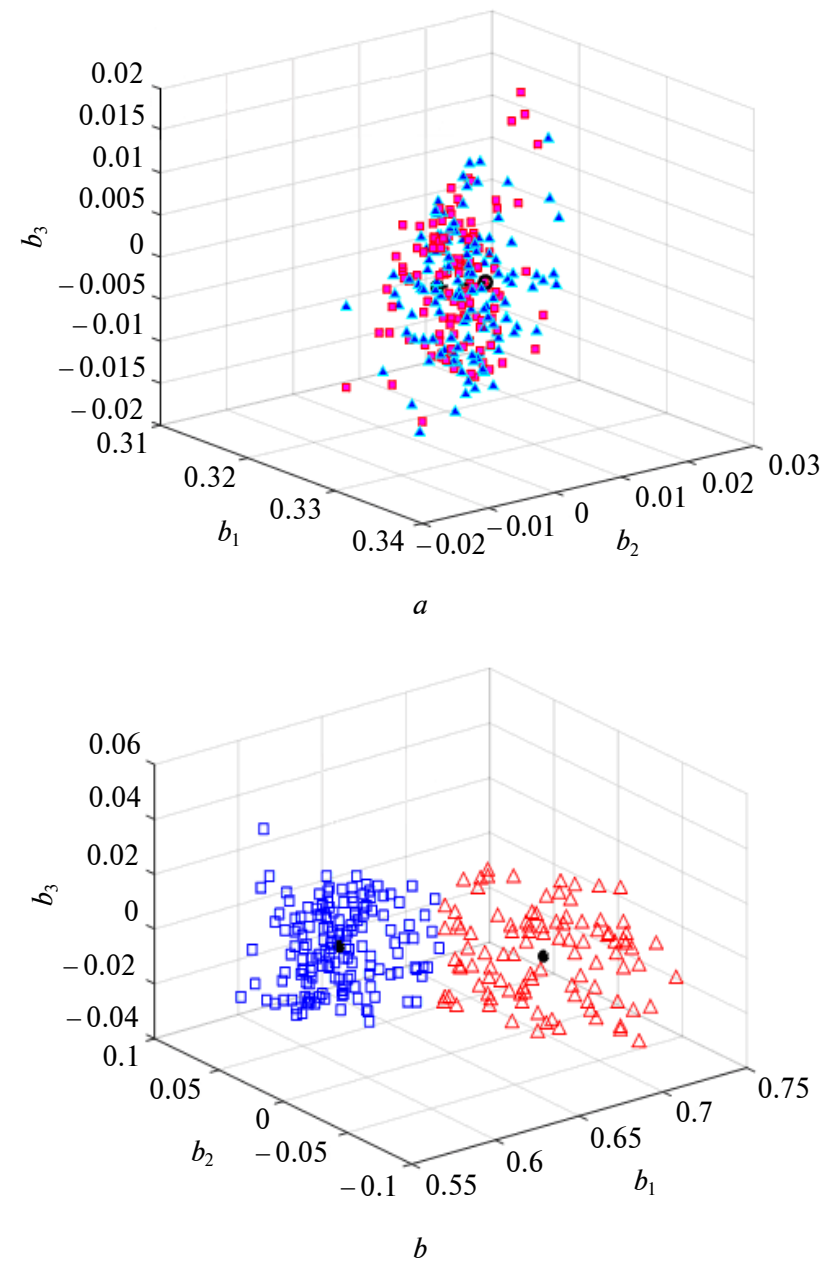

Fig. 10. Coefficients $b_{1}-b_{3}$ for odd and even cardiocycles: $a-$ absence of $\mathrm{T}$ wave alternans: $\mathbf{D}$ - odd, $\boldsymbol{A}$ - even, $\mathbf{D}-$ center of the first cluster, $\mathbf{O}$ - center of the second cluster, - - - distance between the centres of the clusters; $b-$ presence of $T$ wave alternans: $\square-$ even beats, $\Delta-$ odd beats

As a quantitative characteristic for ALP presence identification, the sum of the squares of $b_{i j}$ coefficients, which correspond to the centers of the clusters for even and odd cardiocycles, is proposed to use. Suppose that $C_{\text {odd }}\left(b_{\text {odd } 1}, b_{\text {odd } 2}, \ldots, b_{\text {odd } S}\right)$ and $C_{\text {even }}\left(b_{\text {even } 1}, b_{\text {even } 2}, \ldots, b_{\text {even } S}\right)$ are the centers of the clusters for even and odd cardiocycles, then

$$
H_{\text {odd }}=\sum_{i=1}^{S}\left(b_{\text {odd }}\right)_{i}^{2}, \quad H_{\text {even }}=\sum_{i=1}^{S}\left(b_{\text {even }}\right)_{i}^{2}
$$

where $S$ is the selected number coefficients $b_{i}$, which correspond to the principal eigenvectors $\mathbf{V}_{i}$. Significant differences between the values of the parameters obtained by decomposition in the basis of eigenvectors for $\mathrm{T}$ waves from even and odd cardiocycles indicate the presence of TWA.

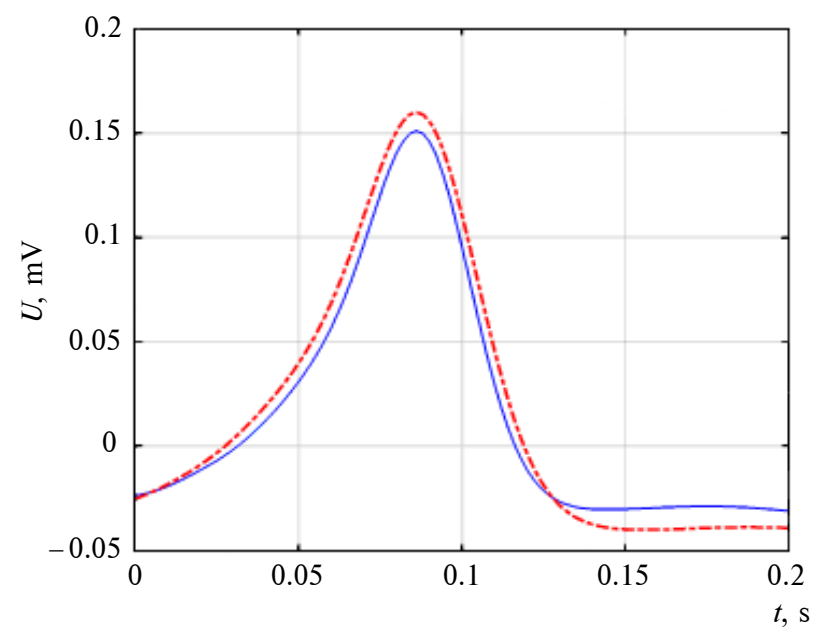

Fig. 11. The basic shapes of $\mathrm{T}$ wave in even and odd cardiac cycles in the presence of micro-TWA: - - basic shape for odd beats; --.-- - basic shape for even beats

Analyzing the features of $\mathrm{T}$ wave alternans identification by analysis in time domain, cluster analysis of the Lorentz scattergrams and principal component analysis, it should be noted that, since the phenomenon of TWA may relate to changes in the amplitude, shape, and time, it is reasonable to use several different approaches for a comprehensive study of this process. For example, the analysis of TWA in the time domain or by using Lorentz scattergrams reveals the alternans of $T$ wave amplitude, but does not provide information about changing of its morphology. Investigations have shown that the PCA method in addition to the identification of alternans in the amplitude of $\mathrm{T}$ wave, can also reveal beatto-beat variability of its shape.

\section{Conclusions}

The combined methods for the analysis of lowamplitude components of electrocardiogram based on the creation of eigensubspaces of signals and noise 
by decomposition in the basis of eigenvectors, principal component analysis, and wavelet analysis are developed. The proposed techniques allow the selection from the noisy ECGs of low amplitude components that are markers of cardiac electrical instability.

Identification of markers of cardiac electrical instability may be based on the use of a broad class of algorithms - from the conventional analysis in time and frequency domains to the complex procedures of pattern recognition. However, at this stage wide application of many approaches to the analysis of markers of cardiac electrical instability is limited in clinical practice, due to the ambiguity of medical interpretation, and demands additional clinical studies. Thus, the directions for further research are improvement of theory-based methods and algorithms for detection of low-amplitude components of ECG for early prediction of potentially dangerous arrhythmias and arrangement of wide clinical tests.

\section{Acknowledgment}

The study was supported by EU-financed Horizon-2020 project AMMODIT (Grant Number MSCA-RISE 645672).

\section{References}

[1] New Methods of Electrocardiography, S.V. Grachev et al., eds., Moscow, Russia: Tekhnosfera, 2007 (in Russian).

[2] G. Breithardt et al., "Standards for analysis of ventricular late potentials using high-resolution or signal-averaged electrocardiography: A statement by a task force committee of the European society of Cardiology, the American heart association, and the American college of Cardiology", J. Am. College Cardiol., vol. 17, no. 5, pp. 999-1006, 1991. doi: 10.1016/07351097(91)90822-Q

[3] N.G. Ivanushkina and K.A. Ivanko, Digital Processing of Low-Amplitude Components of Electrocardiosignals. Kyiv, Ukraine: NTUU KPI, 2014 (in Ukrainian).

[4] N.A. Matveyeva et al., "Combined method for detection of atrial late potentials", in Proc. IEEE 33th Int. Sci. Conf. Electron. Nanotechnol., Kyiv, Ukraine, 2013, pp. 285-289. doi: 10.1109/ELNANO.2013.6552080

[5] S.M. Narayan, "T wave Alternans and the susceptibility to ventricular Arrhythmias", J. Am. College Cardiol., vol. 47, no. 2, pp. 269-281, 2006. doi: 10.1016/j.jacc.2005.08.066

[6] M. Walker, "Repolarization alternans: Implications for the mechanism and prevention of sudden cardiac death", Cardiovascular Res., vol. 57, no. 3, pp. 599-614, 2003. doi: 10.1016/S0008-6363(02)00737-X

[7] A.L. Goldberger et al., "PhysioBank, PhysioToolkit, and PhysioNet: Components of a new research resource for complex physiologic signals", Circulation, vol. 101, no. 23, pp. 215-220, 2000. doi: 10.1161/01.CIR.101.23.e215

[8] G.B. Moody, "The PhysioNet / computers in cardiology challenge 2008: T wave alternans", Computers in Cardiology, vol. 35, pp. 505-508, 2008. doi: 10.1109/CIC.2008.4749089

[9] Y. Karplyuk et al., "Peculiarities of T wave alternans detection and evaluation", in Proc. IEEE 35th Int. Sci. Conf. Electron. Nanotechnol., Kyiv, Ukraine, 2015, pp. 356-361. doi: 10.1109/ELNANO.2015.7146909

[10] F. Castells et al., "Principal component analysis in ECG signal processing", EURASIP J. Adv. Signal Processing, vol. 2007, 21 p., 2007. doi: $10.1155 / 2007 / 74580$

[11] C. Saritha et al., "ECG signal analysis using wavelet transforms", Bulg. J. Phys., vol. 35, pp. 68-77, 2008.

[12] F. Castells et al., "Morphological descriptors based on eigen value decomposition for P-wave analysis", Computers in Cardiology, vol. 35, pp. 245-248, 2008. doi: 10.1109/CIC.2008.4749023

[13] R. Simoliuniene et al., "Principal component analysis based method for detection and evaluation of ECG T wave alternans", Computers in Cardiology, vol. 35, pp. 521-524, 2008. doi: 10.1109/CIC.2008.4749152

К.О. Іванько, Н.Г. Іванушкіна, Є.С. Карплюк

\section{ВИЯВЛЕННЯ ТА ОЦІНЮВАННЯ ЕЛЕКТРОКАРДІОГРАФІЧНИХ МАРКЕРІВ ЕЛЕКТРИЧНОЇ НЕСТАБІЛЬНОСТІ СЕРЦЯ}

Проблематика. Розробка методів ідентифрікації та оцінювання ранніх ознак захворювань серця дає змогу виявити порушення в роботі серця на початковій стадії. У статті розглядаються методи ранньої діагностики серцево-судинної системи з використанням електрокардіографрічних маркерів електричної нестабільності міокарда.

Мета дослідження. Виявлення низькоамплітудних компонент електрокардіосигналів, які неможливо проаналізувати за допомогою стандартних процедур оцінювання електрокардіограми (ЕКГ), із використанням сучасних методів реєстрації, цифрової обробки електрокардіосигналів і електрокардіографрії високого розділення.

Методика реалізації. Для виявлення діагностичних ознак, пов'язаних з електричною нестабільністю міокарда, зміни в реальних і змодельованих електрокардіосигналах були вивчені з використанням різних видів аналізу: в часовій і частотній областях, скатерограм, кластерного аналізу, вейвлет-аналізу та аналізу головних компонент.

Результати досліджень. Розроблені комбіновані методи аналізу низькоамплітудних компонент електрокардіосигналів дали змогу виконати виявлення пізніх потенціалів, а також альтернації Т-зубця на ЕКГ, які є маркерами електричної нестабільності міокарда. 
Висновки. Проведено виявлення та оцінювання тонких проявів електричної активності серця. Використання запропонованого методу дало змогу виділити сплески пізніх потенціалів на фоні шуму і визначити часову область їх локалізації.

Ключові слова: електрокардіографрія високого розділення; пізні потенціали; електрична альтерація Т-зубця; маркери електричної нестабільності міокарда; кластерний аналіз; аналіз головних компонент; власні вектори базису; вейвлет-аналіз.

Е.О. Иванько, Н.Г. Иванушкина, Е.С. Карплюк

ВЫЯВЛЕНИЕ И ОЦЕНИВАНИЕ ЭЛЕКТРОКАРДИОГРАФИЧЕСКИХ МАРКЕРОВ ЭЛЕКТРИЧЕСКОЙ НЕСТАБИЛЬНОСТИ СЕРДЦА

Проблематика. Разработка методов идентификации и оценивания ранних признаков заболеваний сердца позволяет выявить нарушения в работе сердца на начальной стадии. В статье рассматриваются методы ранней диагностики сердечнососудистой системы с использованием электрокардиографических маркеров электрической нестабильности миокарда.

Цель исследования. Выявление низкоамплитудных компонентов электрокардиосигналов, которые невозможно проанализировать при помощи стандартных процедур оценивания электрокардиограммы (ЭКГ), с использованием современных методов регистрации, цифровой обработки электрокардиосигналов и электрокардиографии высокого разрешения.

Методика реализации. Для выявления диагностических признаков, связанных с электрической нестабильностью миокарда, изменения в реальных и смоделированных электрокардиосигналах были изучены с использованием различных видов анализа: во временной и частотной областях, скатерограмм, кластерного анализа, вейвлет-анализа и анализа главных компонент.

Результаты исследований. Разработанные комбинированные методы анализа низкоамплитудных компонент электрокардиосигналов позволили выполнить обнаружение поздних потенциалов, а также альтернацию Т-зубца ЭКГ, которые являются маркерами электрической нестабильности миокарда.

Выводы. Проведено выявление и оценивание тонких проявлений электрической активности сердца. Использование предложенного метода позволило выделить всплески поздних потенциалов на фоне шума и определить временную область их локализации.

Ключевые слова: электрокардиография высокого разрешения; поздние потенциалы; электрическая альтернация Т-зубца; маркеры электрической нестабильности миокарда; кластерный анализ; анализ главных компонент; собственные векторы базиса; вейвлет-анализ.

Рекомендована Радою

факультету прикладної математики

КПІ ім. Ігоря Сікорського
Надійшла до редакції

26 грудня 2016 року 